\title{
3 \\ GDP per Head and Labour Productivity
}

A breakdown of GDP per head into labour productivity and the amount of labour used per person can be made. Thus, GDP per person (GDP/N) will be expressed as GDP per hour worked $(\mathrm{GDP} / \mathrm{H})$, a measure of labour productivity, times the number of hours worked per person $(\mathrm{H} / \mathrm{N})$, a measure of effort.

$$
\mathrm{GDP} / \mathrm{N}=\mathrm{GDP} / \mathrm{H} * \mathrm{H} / \mathrm{N}
$$

And using lower case to denote rates of variation,

$$
(\mathrm{gdp} / \mathrm{n})=(\mathrm{gdp} / \mathrm{h})+(\mathrm{h} / \mathrm{n})
$$

GDP per head and per hour worked evolved alongside over 1850 2015, even though labour productivity grew at a faster pace-labour productivity increased 23-fold against GDP per head 16-fold-as the amounts of hours worked per person shrank-from about $1000 \mathrm{~h}$ per person-year to less than 700-(Table 3.1 and Fig. 3.1). Thus, it can be claimed that gains in output per head are fully attributable to productivity gains, with phases of accelerating GDP per head, such as the 1920s

L. Prados de la Escosura, Spanish Economic Growth, 1850-2015,

Palgrave Studies in Economic History, DOI 10.1007/978-3-319-58042-5_3 
Table 3.1 GDP per head growth and its components, 1850-2015 (\%) (average yearly logarithmic rates)

\begin{tabular}{lccc}
\hline & Per capita GDP & GDP/hour & Hours/population \\
\hline 1850-2015 & 1.7 & 1.9 & -0.2 \\
Pane/ A & & & \\
$1850-1950$ & 0.7 & 0.8 & -0.1 \\
$1950-1974$ & 5.3 & 5.8 & -0.5 \\
$1974-2007$ & 2.5 & 2.7 & -0.1 \\
$2007-2015$ & -0.8 & 1.3 & -2.1 \\
Panel B & & & \\
$1850-1883$ & 1.3 & 1.2 & 0.0 \\
$1883-1920$ & 0.6 & 0.8 & -0.2 \\
$1920-1929$ & 2.8 & 3.1 & -0.3 \\
$1929-1950$ & -0.9 & -1.0 & 0.1 \\
$1950-1958$ & 5.0 & 5.1 & -0.1 \\
$1958-1974$ & 5.5 & 6.1 & -0.7 \\
$1974-1984$ & 1.4 & 5.6 & -4.1 \\
$1984-1992$ & 4.2 & 2.7 & 1.5 \\
$1992-2007$ & 2.4 & 0.7 & 1.7 \\
$2007-2013$ & -1.9 & 1.6 & -3.5 \\
$2013-2015$ & 2.6 & 0.5 & 2.1 \\
Pane/ C & & & \\
$1850-1855$ & 2.1 & 2.3 & -0.2 \\
$1855-1866$ & 0.4 & 0.1 & 0.3 \\
$1866-1873$ & 2.9 & 2.5 & 0.4 \\
$1873-1883$ & 0.6 & 1.0 & -0.4 \\
$1883-1892$ & 0.6 & 0.9 & -0.4 \\
$1892-1901$ & 0.7 & 0.6 & 0.1 \\
$1901-1913$ & 0.5 & 0.7 & -0.2 \\
$1913-1918$ & -0.6 & -0.2 & -0.4 \\
$1918-1929$ & 3.1 & 3.4 & -0.3 \\
$1929-1935$ & -1.5 & -1.6 & 0.0 \\
$1935-1939$ & -6.9 & 4.5 & -1.0 \\
$1939-1944$ & 4.8 & -1.6 & 0.4 \\
$1944-1950$ & -1.0 & & 0.7 \\
\hline & & &
\end{tabular}

or the Golden Age (1950-1974), matching those of faster labour productivity growth.

A closer look at the last four decades reveals, however, significant discrepancies over long swings. In fact, a pattern can be observed 


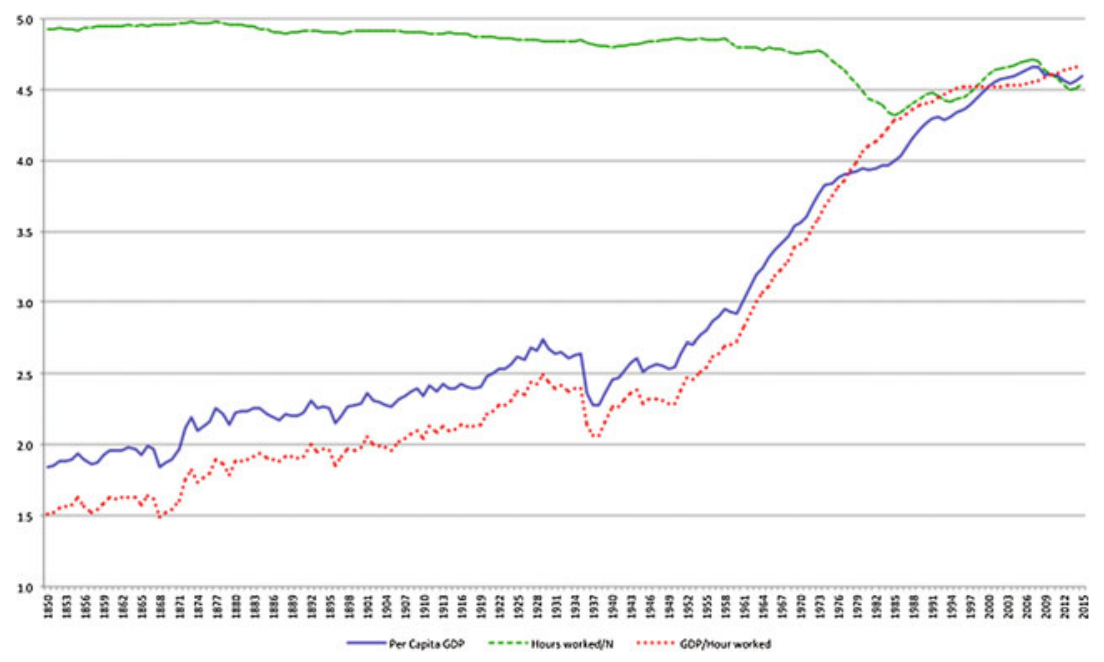

Fig. 3.1 Real per capita GDP and its components, 1850-2015 (logs)

according to which phases of acceleration in labour productivity correspond to those of GDP per person slowdown, and vice versa (Fig. 3.2). Thus, periods of sluggish (1974-1984) or negative (2007-2013) per capita GDP growth paralleled episodes of vigorous or recovering productivity growth, although only in the first case, during the 'transition to democracy' decade, labour productivity offset the sharp contraction in hours worked-resulting from unemployment - and prevented a decline in GDP per head. Conversely, the years between Spain's accession to the European Union (1985) and the eve of the Great Recession (2007), particularly since 1992, exhibited substantial per capita GDP gains, while labour productivity slowed down. Thus, during the three decades after Spain joined the EU, in which GDP per head doubled, growing at 3.0\% per year, more than half was contributed by the increase in hours worked per person.

Thus, it can be concluded that since the mid-1970s, the Spanish economy has been unable to combine employment and productivity growth, with the implication that sectors that expanded and created new jobs (mostly in construction and services) were less successful in attracting investment and technological innovation. Actually, labour 


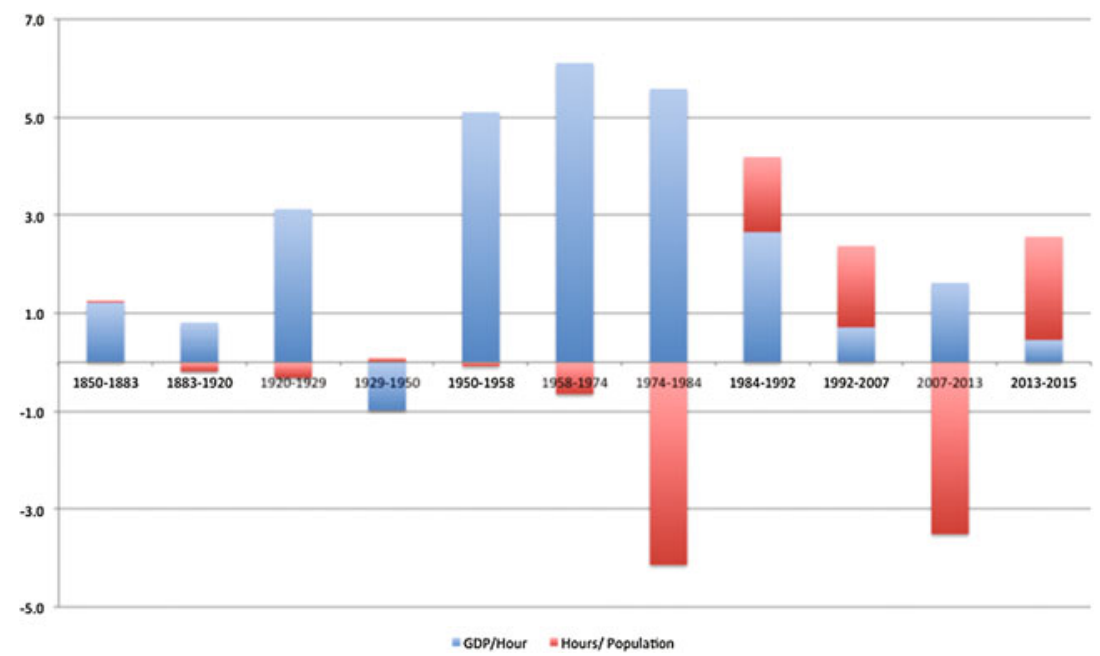

Fig. 3.2 Real per capita GDP growth and its breakdown over long swings, 1850-2015 (logarithmic growth rates) (\%). Note per capita GDP growth results from adding up the growth rates of GDP/hour and hours per person

productivity in construction and services grew at a yearly rate of -0.2 and $0.3 \%$, respectively, compared to $1.1 \%$ for the overall economy over 1985-2007 (Table 3.2).

Gains in aggregate labour productivity can be broken down into the contribution made by the increase in output per hour worked in each economic sector (internal productivity) and by the shift of labour from less productive to more productive sectors (structural change). ${ }^{1}$ The level of aggregate labour productivity $(\mathrm{A})$, which is obtained by dividing gross value added (GVA) by the number of hours worked $(\mathrm{H})$ for the economy as a whole in the year $\mathrm{t}$, can be expressed as the result of adding up labour productivity $\left(\mathrm{GVA}_{\mathrm{i}} / \mathrm{H}_{\mathrm{i}}\right)$ for each economic sector $\mathrm{i}(\mathrm{i}=1,2, \ldots, \mathrm{n})$, weighted by each sector's contribution to total hours worked $\left(\mathrm{H}_{\mathrm{i}} / \mathrm{H}\right){ }^{2}$

$$
\mathrm{A}_{\mathrm{t}}=(\mathrm{GVA} / \mathrm{H})_{\mathrm{t}}=\Sigma\left(\mathrm{GVA}_{\mathrm{i}} / \mathrm{H}_{\mathrm{i}}\right)_{\mathrm{t}}\left(\mathrm{H}_{\mathrm{i}} / \mathrm{H}\right)_{\mathrm{t}}=\Sigma\left(\mathrm{A}_{\mathrm{it}} \mathrm{U}_{\mathrm{it}}\right)
$$

where $A_{i}$ is gross value added per hour worked in sector $i$, and $U_{i}$ is the contribution of sector i to total hours worked. 
Table 3.2 Labour productivity growth by sectors, 1850-2015 (\%) (GVA per hour worked) (average yearly logarithmic rates)

\begin{tabular}{|c|c|c|c|c|c|}
\hline & Agriculture & Industry & Construction & Services & Total \\
\hline $1850-2015$ & 2.3 & 2.5 & 1.8 & 1.4 & 1.9 \\
\hline \multicolumn{6}{|l|}{ Panel A } \\
\hline 1850-1950 & 0.2 & 1.4 & 0.7 & 0.9 & 0.8 \\
\hline 1950-1974 & 6.2 & 6.4 & 5.5 & 3.4 & 6.0 \\
\hline 1974-2007 & 6.1 & 3.4 & 1.6 & 1.4 & 2.5 \\
\hline 2007-2015 & 1.8 & 2.2 & 4.8 & 0.7 & 1.4 \\
\hline \multicolumn{6}{|l|}{ Panel B } \\
\hline 1850-1883 & 0.6 & 3.2 & 2.1 & 1.1 & 1.2 \\
\hline 1883-1920 & 0.7 & 0.4 & 0.4 & 1.1 & 0.8 \\
\hline 1920-1929 & 2.6 & 3.4 & 3.2 & 1.3 & 2.9 \\
\hline 1929-1950 & -2.2 & -0.7 & -2.1 & 0.3 & -1.0 \\
\hline 1950-1958 & 6.0 & 6.7 & -2.9 & 2.5 & 5.0 \\
\hline 1958-1974 & 6.3 & 6.2 & 9.7 & 3.8 & 6.5 \\
\hline 1974-1984 & 8.0 & 6.5 & 5.7 & 3.8 & 5.6 \\
\hline 1984-1992 & 9.3 & 2.1 & 2.2 & 0.4 & 2.1 \\
\hline 1992-2007 & 3.2 & 2.1 & -1.5 & 0.3 & 0.6 \\
\hline 2007-2013 & 3.1 & 2.0 & 7.4 & 1.0 & 1.8 \\
\hline 2013-2015 & -2.1 & 2.9 & -3.0 & -0.2 & 0.1 \\
\hline \multicolumn{6}{|l|}{ Panel C } \\
\hline 1850-1855 & 3.4 & 4.7 & 2.0 & 0.5 & 2.7 \\
\hline 1855-1866 & -0.7 & 2.0 & 2.1 & 0.2 & 0.0 \\
\hline 1866-1873 & 2.6 & 4.0 & -0.8 & 2.3 & 2.6 \\
\hline 1873-1883 & -0.6 & 3.3 & 4.0 & 1.4 & 0.8 \\
\hline 1883-1892 & 0.7 & 1.4 & 0.1 & 0.7 & 0.9 \\
\hline 1892-1901 & 0.6 & 0.9 & 0.9 & 0.0 & 0.5 \\
\hline 1901-1913 & 0.0 & -0.2 & 2.7 & 1.4 & 0.7 \\
\hline 1913-1918 & 1.5 & -0.6 & -11.2 & 0.9 & 0.3 \\
\hline 1918-1929 & 2.7 & 2.6 & 5.5 & 2.3 & 3.1 \\
\hline 1929-1935 & 0.4 & -3.9 & -8.8 & -1.8 & -1.4 \\
\hline 1935-1939 & -9.7 & -1.0 & -15.8 & -1.7 & -5.8 \\
\hline 1939-1944 & 2.0 & 4.3 & 17.4 & 4.8 & 3.9 \\
\hline 1944-1950 & -3.4 & -1.3 & -2.5 & -0.3 & -1.5 \\
\hline
\end{tabular}


Using lower case letters to represent rates of change,

$$
\mathrm{a}_{\mathrm{t}}=\Sigma \mathrm{a}_{\mathrm{it}} \mathrm{U}_{\mathrm{it}}+\Sigma \mathrm{A}_{\mathrm{it}} \mathrm{u}_{\mathrm{it}}
$$

The method usually employed in this calculation, shift-share analysis, involves estimating, in the first place, internal productivity growth (the first term on the right-hand side of expression (4), that is, the result obtained by adding up the labour productivity growth of GVA per hour worked in each economic sector weighted by the initial composition of employment (expressed in hours worked). The difference between aggregate productivity and internal productivity will then provide the contribution of structural change. Structural change would have made a positive contribution to productivity growth over $1850-1974$ by shifting labour from agriculture into industry (Table 3.3, column 3 and Fig. 3.3). Conversely, since 1985, structural change, represented by the shift of labour from both agriculture and industry into services, would have slowed down aggregate productivity growth. Carrying out the shift-share analysis at a high level of aggregation, that is, between main economic sectors, precludes a more nuanced picture, as within industry and services there were shifts from sectors of lower productivity levels or growth rates to others of higher productivity levels or more intense growth.

Nonetheless, the shift-share analysis is based on the assumption that, in the absence of labour shift between sectors, each sector's productivity would have been identical to the actual ones. This is an unrealistic assumption when labour is rapidly absorbed by industry and services and productivity tends to stagnate or even decline in these sectors. This seems to be the case in Spain. ${ }^{3}$ It would appear more plausible to assume that agricultural productivity partly improved, say, between 1950 and 1975, due to the reduction in the number of hours worked in the sector. Furthermore, during the 'transition to democracy' (1975-1985) GVA per hour worked in industry would have grown more slowly had employment not fallen in the sector, a result of industrial restructuring that shrank or eliminated less competitive branches. Thus, the result for the contribution of structural change to productivity growth obtained 
Table 3.3 Labour productivity growth and structural change, 1850-2015 (\%) (average yearly logarithmic rates)

\begin{tabular}{|c|c|c|c|c|c|}
\hline & $\begin{array}{l}\text { GVA/hour } \\
\text { worked }\end{array}$ & $\begin{array}{l}\text { Internal } \\
\text { productivity } \\
\text { (shift-share) }\end{array}$ & $\begin{array}{l}\text { Structural } \\
\text { change } \\
\text { (lower } \\
\text { bound) }\end{array}$ & $\begin{array}{l}\text { Internal } \\
\text { productivity } \\
\text { (modified } \\
\text { shift-share) }\end{array}$ & $\begin{array}{l}\text { Structural } \\
\text { change } \\
\text { (upper } \\
\text { bound) }\end{array}$ \\
\hline $1850-2015$ & 1.9 & 2.1 & -0.2 & 1.2 & 0.7 \\
\hline \multicolumn{6}{|l|}{ Panel A } \\
\hline 1850-1950 & 0.8 & 0.5 & 0.2 & 0.4 & 0.3 \\
\hline 1950-1974 & 6.0 & 5.4 & 0.6 & 3.6 & 2.4 \\
\hline 1974-2007 & 2.5 & 2.9 & -0.4 & 1.6 & 0.9 \\
\hline 2007-2015 & 1.4 & 1.5 & -0.1 & -0.2 & 1.6 \\
\hline \multicolumn{6}{|l|}{ Panel B } \\
\hline 1850-1883 & 1.2 & 1.1 & 0.1 & 1.1 & 0.1 \\
\hline 1883-1920 & 0.8 & 0.7 & 0.1 & 0.6 & 0.2 \\
\hline 1920-1929 & 2.9 & 2.5 & 0.5 & 1.5 & 1.5 \\
\hline 1929-1950 & -1.0 & -1.2 & 0.3 & -1.4 & 0.4 \\
\hline 1950-1958 & 5.0 & 4.6 & 0.4 & 3.0 & 2.0 \\
\hline 1958-1974 & 6.5 & 5.9 & 0.6 & 4.4 & 2.1 \\
\hline 1974-1984 & 5.6 & 5.6 & 0.0 & 4.5 & 1.1 \\
\hline 1984-1992 & 2.1 & 2.3 & -0.3 & 0.8 & 1.3 \\
\hline 1992-2007 & 0.6 & 0.7 & -0.1 & 0.0 & 0.7 \\
\hline 2007-2013 & 1.8 & 2.1 & -0.3 & -0.1 & 2.0 \\
\hline 2013-2015 & 0.1 & -0.1 & 0.1 & -0.3 & 0.4 \\
\hline \multicolumn{6}{|l|}{ Panel C } \\
\hline 1850-1855 & 2.7 & 2.8 & -0.2 & 2.5 & 0.1 \\
\hline 1855-1866 & 0.0 & -0.1 & 0.1 & -0.1 & 0.1 \\
\hline $1866-1873$ & 2.6 & 2.6 & 0.1 & 2.4 & 0.3 \\
\hline 1873-1883 & 0.8 & 0.5 & 0.3 & 0.4 & 0.4 \\
\hline 1883-1892 & 0.9 & 0.8 & 0.1 & 0.7 & 0.2 \\
\hline 1892-1901 & 0.5 & 0.5 & 0.0 & 0.4 & 0.1 \\
\hline 1901-1913 & 0.7 & 0.4 & 0.3 & 0.2 & 0.5 \\
\hline 1913-1918 & 0.3 & 0.5 & -0.2 & 0.4 & -0.1 \\
\hline 1918-1929 & 3.1 & 2.7 & 0.4 & 1.8 & 1.2 \\
\hline 1929-1935 & -1.4 & -1.4 & 0.0 & -2.3 & 0.8 \\
\hline 1935-1939 & -5.8 & -5.9 & 0.2 & -8.0 & 2.2 \\
\hline 1939-1944 & 3.9 & 4.0 & -0.1 & 3.7 & 0.2 \\
\hline 1944-1950 & -1.5 & -2.2 & 0.8 & -2.7 & 1.2 \\
\hline
\end{tabular}




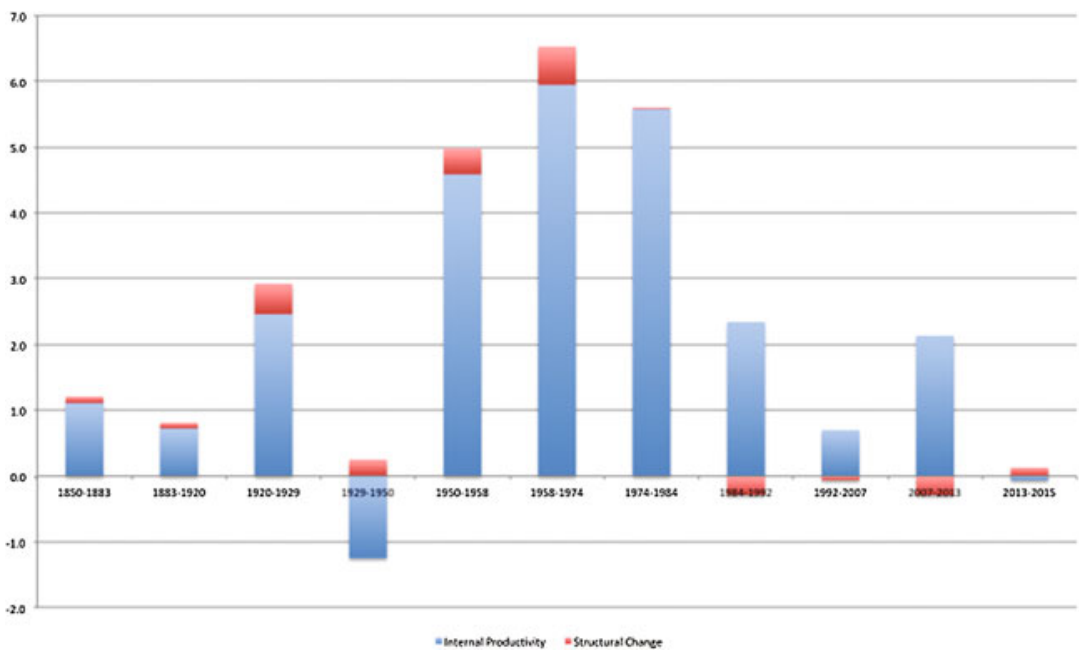

Fig. 3.3 Labour productivity growth and structural change over long swings: shift-share, 1850-2015 (logarithmic growth rates) (\%)

using the conventional shift-share analysis (Table 3.3) would arguably represent a lower bound.

Alternatively, an upper bound can be derived using Broadberry's modified version of the shift-share analysis. ${ }^{4}$ The contribution of structural change is derived by subtracting from aggregate productivity the figure that would result by weighting output per hour worked growth in each sector according to its contribution to total employment in the initial year, but with an exception for those sectors whose contribution to employment falls (e.g. agriculture over the entire time span considered and industry since 1975). In such a case, the differential between the rate of variation in hours worked for the economy as a whole and for the relevant sector would be subtracted from the latter's productivity growth. ${ }^{5}$ As Table 3.3 shows, the difference between upper and lower bounds can be significant for some periods.

Structural change, derived with the modified shift-share approach, would account for 38\% of the aggregate productivity growth achieved over the last 166 years. This figure is not far below from Broadberry's own findings for Germany and the USA. ${ }^{6}$ Over 1850-1950, its 


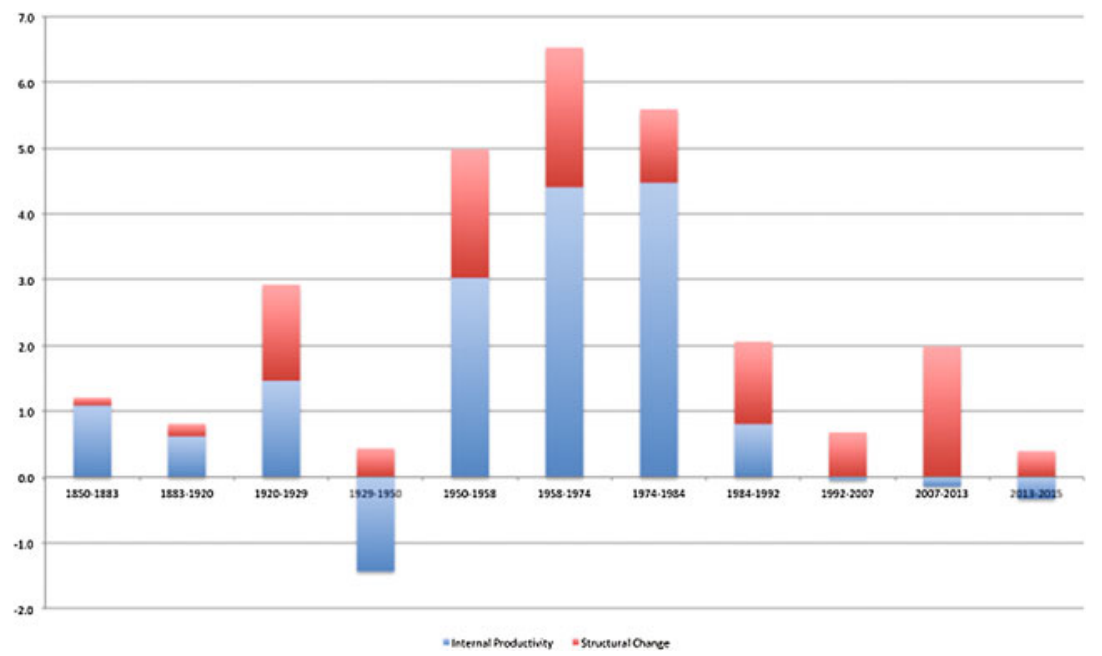

Fig. 3.4 Labour productivity growth and structural change over long swings: modified shift-share, 1850-2015 (logarithmic growth rates) (\%)

contribution would reach two-fifths of labour productivity growth, against the one-fourth suggested by the conventional shift-share approach. A closer look indicates that structural transformation made a larger contribution to productivity growth between the 1870s and 1929, with decade 1874-1883, the long decade before World War I, and the 1920 s as the most intense episodes (Fig. 3.4).

According to the modified shift-share analysis, it is in the Golden Age (1950-1974) when structural change would have made the larger and more sustained contribution to productivity growth.

Since 1975 and up to the eve of the Great Recession (2007), structural change accounted for more than one-third of the increase in aggregate labour productivity and avoided an even deeper productivity deceleration after 1984. This result is at odds with the negative contribution of structural change to productivity advance suggested by the conventional shift-share analysis. In this phase, the transfer of labour away from agriculture (which still absorbed one-fifth of the total number of hours worked in 1975 and, since then, hours worked in agriculture declined at yearly rate of $-4 \%$ to 2007 ) was accompanied by a sustained destruction 
of employment in less competitive manufacturing industries, which intensified during the 'transition to democracy' decade $(-3.8 \%$ yearly decline of hours worked in industry during 1974-1984). Since 2007, structural change prevented labour productivity from stalling contributing a moderate increase in output per hour worked during the Great Recession.

A clearer picture of the evolution of the number of hours worked per person, $(\mathrm{H} / \mathrm{N})$, is obtained by breaking it down into its components (Table 3.4). Thus, $(\mathrm{H} / \mathrm{N})$ equals hours worked per full-time equivalent worker, $\mathrm{L},(\mathrm{H} / \mathrm{L})$, times the participation rate-that is, the ratio of $\mathrm{L}$, to the working age population, WAN-, (L/WAN), times the share of WAN in total population, $\mathrm{N},(\mathrm{WAN} / \mathrm{N})$,

$$
(\mathrm{H} / \mathrm{N})=(\mathrm{H} / \mathrm{L}) *(\mathrm{~L} / \mathrm{WAN}) *(\mathrm{WAN} / \mathrm{N})
$$

Table 3.4 Hours worked per head growth and its composition, 1850-2015 (\%) (average yearly logarithmic rates)

\begin{tabular}{cllcr}
\hline & $\begin{array}{l}\text { Hours } \\
\text { worked/N }\end{array}$ & $\begin{array}{l}\text { Hours/FTE } \\
\text { worker }\end{array}$ & $\begin{array}{l}\text { FTE } \\
\text { worker/WAN }\end{array}$ & WAN/N \\
\hline $1850-2015$ & -0.2 & -0.3 & 0.0 & 0.0 \\
Panel A & & & & \\
1850-1950 & -0.1 & -0.1 & 0.0 & 0.1 \\
$1950-1974$ & -0.5 & -0.5 & 0.3 & -0.3 \\
$1974-2007$ & -0.1 & -0.6 & 0.2 & 0.3 \\
2007-2015 & -2.1 & 0.2 & -1.8 & -0.5 \\
Panel B & & & & \\
$1850-1883$ & 0.0 & 0.0 & 0.0 & 0.0 \\
$1883-1920$ & -0.2 & -0.1 & -0.1 & 0.0 \\
$1920-1929$ & -0.3 & -0.5 & 0.0 & 0.1 \\
$1929-1950$ & 0.1 & -0.1 & -0.1 & -0.3 \\
$1950-1958$ & -0.1 & -0.3 & 0.6 & -0.2 \\
$1958-1974$ & -0.7 & -0.6 & 0.2 & 0.3 \\
$1974-1984$ & -4.1 & -1.7 & -2.8 & 0.6 \\
$1984-1992$ & 1.5 & -0.4 & 1.3 & 0.2 \\
$1992-2007$ & 1.7 & 0.0 & 1.5 & -0.5 \\
$2007-2013$ & -3.5 & 0.3 & -3.3 & -0.5 \\
$2013-2015$ & 2.1 & -0.1 & 2.7 & $(c 0 n$ \\
\hline
\end{tabular}


Table 3.4 (continued)

\begin{tabular}{lcccr}
\hline & $\begin{array}{l}\text { Hours } \\
\text { worked/N }\end{array}$ & $\begin{array}{l}\text { Hours/FTE } \\
\text { worker }\end{array}$ & $\begin{array}{l}\text { FTE } \\
\text { worker/WAN }\end{array}$ & WAN/N \\
\hline Panel C & & & & \\
$1850-1855$ & -0.2 & -0.3 & 0.0 & 0.1 \\
$1855-1866$ & 0.3 & 0.1 & 0.0 & 0.2 \\
$1866-1873$ & 0.4 & 0.2 & 0.3 & -0.1 \\
$1873-1883$ & -0.4 & -0.1 & -0.2 & -0.1 \\
$1883-1892$ & -0.4 & -0.1 & -0.2 & -0.1 \\
$1892-1901$ & 0.1 & -0.1 & 0.1 & 0.0 \\
$1901-1913$ & -0.2 & -0.1 & 0.0 & -0.1 \\
$1913-1918$ & -0.4 & -0.3 & -0.3 & 0.1 \\
$1918-1929$ & -0.3 & -0.4 & 0.0 & 0.1 \\
$1929-1935$ & 0.0 & -0.4 & 0.2 & 0.2 \\
$1935-1939$ & -1.0 & 0.0 & -1.3 & 0.2 \\
$1939-1944$ & 0.4 & 0.0 & -0.1 & 0.4 \\
$1944-1950$ & 0.7 & 0.0 & 0.2 & 0.5 \\
\hline
\end{tabular}

That in rates of change (lower case letters) can be expressed as:

$$
(\mathrm{h} / \mathrm{l})=(\mathrm{h} / \mathrm{l})+(\mathrm{l} / \mathrm{wan})+(\text { wan } / \mathrm{n})
$$

The change in hours per full-time equivalent worker-year $(\mathrm{H} / \mathrm{L})$, which fell from 2800 by mid-nineteenth century to less than 1900 at the beginning of the twenty-first century, represents the main driver of the amount of work per person, especially in periods of industrialization and urbanization such as the 1920s (to which the gradual adoption of the $8 \mathrm{~h}$ per day standard also contributed) and the Golden Age (1950-1974) (Fig. 3.5).

Changes in the participation rate (L/WAN) also made a contribution (Fig. 3.6). For example, in the Golden Age (1950-1974), it mitigated the decline in hours worked per person. However, it is since 1975 when the participation rate becomes the main determinant of changes in the amount of hours worked per person. Thus, (L/WAN) accounts for two-thirds of its contraction during the 'transition to democracy' decade (1975-1984). Such a decline was due to a dramatic surge in unemployment, largely resulting from the impact of the oil shocks and the exposure to international competition on traditionally sheltered industrial sectors, plus the return of migrants from Europe. The higher bargaining power of trade unions and industrial restructuring made the rest. Another surge in 


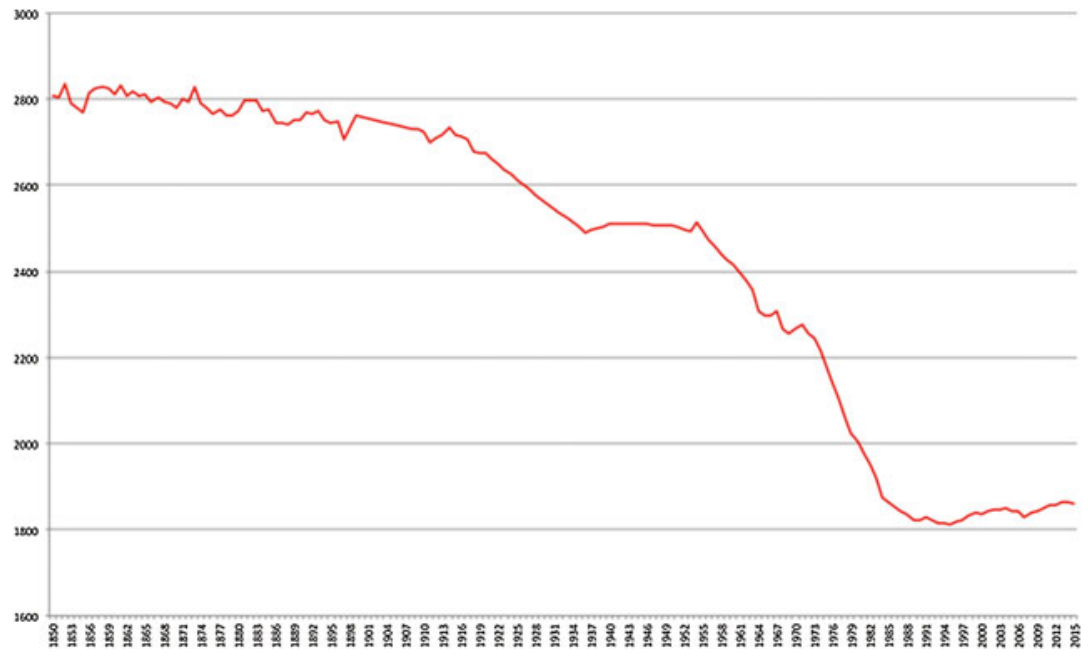

Fig. 3.5 Hours per full-time equivalent worker, 1850-2015

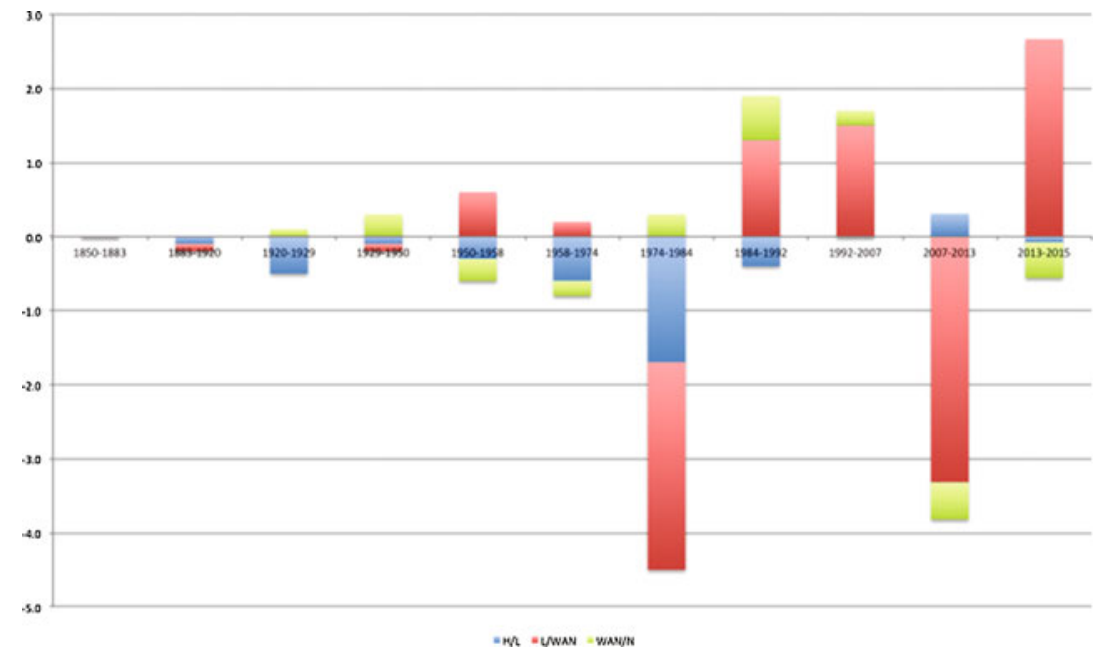

Fig. 3.6 Hours worked per head growth and its breakdown over long swings, 1850-2015 logarithmic growth rates (\%) 
unemployment made the participation rate accountable for most of the reduction in hours worked per person during the Great Recession (20082013).

Conversely, between Spain's EU accession and the Great Recession (1985-2007), the increase in (L/WAN) was the main contributor to the increase in the number of hours worked per person, helped by increasing female participation and the post-1990 inflow of migrants. Again, the rise in the participation rate, as unemployment has gradually declined, is a main actor in the post-2013 recovery in hours worked per person. Lastly, a demographic gift, as the dependency rate fell increasing the share of potentially active over total population, prevented a further decline of hours worked per person during the 1930s, contributed to its recovery in the 1940s and helped the surge in employment over 1985-2007.

\section{Notes}

1. As correctly pointed out by Matthews et al. (1982: 248-254), structural change is not really exogenous as it is caused by the interaction between the supply and demand of resources. Hence, any attempt to establish causal relationships between structural change and growth is flawed. From a historical point of view, however, perfect factor mobility does not exist and, consequently differences of marginal productivity between sectors tend to exist, as the movement of resources from one sector to another does not take place automatically. For this reason, improvements in resource allocation will contribute to growth during a given period of time. It is also the case that even when marginal productivity is the same in different industries, they will not all grow at the same rate. Growth will depend on their use of technological innovation and the existence of increasing returns.

2. I draw on Broadberry (1998) in the subsequent paragraphs.

3. Broadberry (1998) puts forward the idea that if we accept, as proposed by Kindleberger (1967), that labour moving from agriculture to industry and services is surplus labour, then it must be assumed that the hypothetical return of this labour to the agricultural sector would have a negative effect on productivity.

4. It provides an upper bound because it does not take into account differences in levels of physical and human capital per worker across economic sectors. Ideally, the contribution of structural change should be calculated. 
5. In this case, internal productivity would be calculated as $\Sigma \mathrm{a}_{\mathrm{it}}^{\prime} \mathrm{U}_{\mathrm{it}}$, where $\mathrm{a}_{\mathrm{it}}^{\prime}=\mathrm{a}_{\mathrm{it}}-\left(\mathrm{h}_{\mathrm{t}}-\mathrm{h}_{\mathrm{it}}\right)$, if $\mathrm{U}_{\mathrm{it}}<0 \quad$ (h representing hours worked) (Broadberry 1998).

6. Broadberry (1998: 390) finds that, over 1870-1990, structural change would account for up to 45.7 and $50.3 \%$ of productivity growth in Germany $(1.75 \%)$ and the USA (1.4\%), respectively.

\section{References}

Broadberry, S.N. 1998. How Did the United States and Germany Overtake Britain? A Sectoral Analysis of Comparative Productivity Levels. Journal of Economic History 58: 375-407.

Kindleberger, C.P. 1967. European Postwar Growth: The Role of Labor Supply. National Bureau of Economic Research: Princeton.

Matthews, R.C.O., C.H. Feinstein, J.C. Odling-Smee. 1982. British Economic Growth 1856-1973. Oxford: Clarendon Press.

Open Access This chapter is licensed under the terms of the Creative Commons Attribution 4.0 International License (http://creativecommons.org/licenses/by/ $4.0 /$ ), which permits use, sharing, adaptation, distribution and reproduction in any medium or format, as long as you give appropriate credit to the original author(s) and the source, provide a link to the Creative Commons license and indicate if changes were made.

The images or other third party material in this chapter are included in the chapter's Creative Commons license, unless indicated otherwise in a credit line to the material. If material is not included in the chapter's Creative Commons license and your intended use is not permitted by statutory regulation or exceeds the permitted use, you will need to obtain permission directly from the copyright holder.

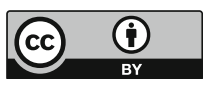

